\title{
Changes in manuscript submission
}

Acta Palaeontologica Polonica 53 (3), 2008: 544-544 doi:http://dx.doi.org/10.4202/app.2008.0313

This is an open-access article distributed under the terms of the Creative Commons

Attribution License (for details please see creativecommons.org), which permits unrestricted use, distribution, and reproduction in any medium, provided the original author and source are credited.

FaF Full text $(99.7 \mathrm{kB})$ 